\title{
PAISAGEM CONCEITUAL: CONSTRUÇÃO TEÓRICA E SUA UTILIZAÇÃO NA EDUCAÇÃO
}

\author{
CONCEPTUAL LANDSCAPE: THEORETICAL CONSTRUCTION AND ITS \\ UTILIZATION IN EDUCATION
}

Luiz Antonio Botelho Andrade ${ }^{67}$

\begin{abstract}
Resumo
Analisamos os diferentes significados expressos para o termo conceito e, a partir de uma síntese, construímos uma formulação original para o conceito de conceito, denominado aqui, metaforicamente, de paisagem conceitual. No contexto desta reflexão epistemológica, postulamos que as paisagens conceituais se sobrepõem aos conceitos semânticos, exclusivos, hipotéticos, operacionais e heurísticos e que, ao permitir ao observador um duplo olhar, para o passado e para o futuro, elas podem se tornar um bom guia cartográfico para deslocamentos teóricos, projetos de pesquisa e de ensino e, assim, contribuir para a atividade docente e a socialização do conhecimento.
\end{abstract}

Palavras-chave: Conceito. Paisagem conceitual. Experiência. Conhecimento.

\begin{abstract}
We analyze the different meanings expressed for the term concept and, from a synthesis, we constructed an original formulation for the concept of concept, here termed metaphorically of conceptual landscape. In the context of this epistemological reflection, we postulate that conceptual landscapes overlap with semantics, exclusives, hypotheticals, operationals and heuristics concepts, and that, by allowing the observer to double look at the past and the future, they can become a good guide cartography for theoretical displacements, elaboration of research and teaching projects and, thus, contribute to the teaching activity and the socialization of knowledge.
\end{abstract}

Keywords: Concept. Conceptual landscape. Experience. Knowledge.

67 Biólogo, Doutor em Imunologia pelo Instituto Pasteur, Professor Associado III do Departamento de Imunobiologia da UFF, membro do Programa de Pós-graduação em Diversidade e Inclusão da UFF, membro do Observatório Internacional de Inclusão, Interculturalidade e Inovação Pedagógica (OIIIIPE). Tem experiência no ensino de ciências, educação inclusiva, epistemologia, produção de filme educativo e divulgação científica. Atual Presidente da Associação Brasileira de Diversidade e Inclusão-ABDIn. E-mail: labauff@yahoo.com.br 


\section{RevistAleph}

\section{Introdução}

São inúmeras as teorias formuladas por diferentes escolas filosóficas, desde a antiguidade, com vistas a explicar a gênese, a produção, o significado e a utilização dos conceitos na linguagem cotidiana e de seu uso mais particular na filosofia, na arte, na ciência e na educação (ABBAGNAMO, 2007). No entanto, nenhuma teoria foi capaz de dar conta das formas tão diversas conforme os conceitos são utilizados nos diferentes sistemas de conhecimento (VUILLEMIN, 1997).

Ainda que não tenhamos a pretensão de construir e propor uma teoria sobre conceito, decidimos aprofundar nossa compreensão sobre o significado e uso deste termo por considerá-lo, de um lado, abstrato, polissêmico e de difícil entendimento mas, por outro, de fundamental importância para a construção e a socialização do conhecimento em todas as áreas do saber humano, ressaltando, assim, o seu uso indispensável na educação.

O conceito, enquanto termo linguístico, está logicamente vinculado à linguagem pelo simples fato de que toda distinção e nomeação são feitas por um ou mais observadores - na linguagem. Logo, quando distinguimos os sentidos do termo "conceito" vis-à-vis de outros termos com significados parecidos - noção, ideia, definição - mas distintos, o fazemos na condição de observadores, ou seja, na linguagem. Retorna-se à linguagem quando constatamos, através de nossas distinções, que os conceitos são objetos mentais e produtos do discurso, portanto, se encontram inseridos no domínio da linguagem (EICHEVERRIA, 1994).

Um marco importante da historicidade do que modernamente denominamos de conceito e sua vinculação com a linguagem teve início na Grécia antiga, com Aristóteles (384 - 322 a.C). Para este filósofo, nós, seres humanos, somos dotados de uma dupla semiótica que nos capacita a falar e a escrever sobre as coisas do mundo, por meio de símbolos linguísticos. No entanto, esta prática denotativa, de falar e escrever sobre alguma coisa, poderia ser dificultada, e mesmo obstaculizada, por uma diferença crucial entre o mundo das coisas e o mundo da linguagem, qual seja: embora o mundo e a linguagem sejam infinitos em suas possibilidades constitutivas (mundo dos objetos) e descritivas (mundo da linguagem), há uma defasagem potencial na prática cotidiana que impediria a linguagem de dar conta, em tempo real, da infinitude do mundo dos objetos, 


\section{RevistAleph}

acrescidos dos acontecimentos. Na impossibilidade desse "dar conta", o que fazemos é utilizar o artifício linguístico de inventar nomes gerais e/ou conceitos para agrupar e designar objetos semelhantes e, com isto, descrever o mundo, segundo nossa real capacidade de memória. Como diria Aristóteles, o nome geral apazígua a memória (ULPIANO, 1989a, b). Jorge Luís Borges (1997) foi ao encontro deste problema quando escreveu o conto "Fumes, o memorioso", no qual o autor relata a estória de um indivíduo que se lembrava dos mínimos detalhes de tudo, desde sempre, mas que, por isso mesmo, não conseguia pensar.

Embora Aristóteles não tenha usado a palavra conceito (nome latino), o nome geral foi a primeira reflexão sobre conceito, pensado, então, como um artifício para que a linguagem pudesse dar conta da infinitude do mundo (objetos e acontecimentos), em todas suas possibilidades descritivas, criativas e comunicacionais (ULPIANO, 1089a, b). Aristóteles contribuiu também com a concepção de conceito como essência das coisas (ABBAGNAMO, 2007). Neste sentido, para Aristóteles, o conceito se identifica com a essência da coisa denotada, aquilo com o qual todo ser não pode ser diferente do que é posto que ele é constituído por uma essência, ou substancia necessária, distinta e distintiva (ABBAGNAMO, 2007). Bertrand Russel (1977) vai tratar este problema como a consciência dos particulares versus a consciência dos universais. Para este autor, "a consciência dos universais chama-se conceber, e o universal que de que temos consciência chama-se conceito" (RUSSEL, 1977, p.218).

Várias outras interpretações estruturais, funcionais e instrumentais têm sido propostas para os conceitos ressaltando as capacidades dos mesmos para descrever, comunicar, organizar, representar, criar, classificar, modelar e até mesmo prever a regularidade de certos acontecimentos, como no caso de certas teorias científicas nas quais o conceito é a própria lei que rege a fenomenologia observada - a relatividade, por exemplo (ABBAGNAMO, 2007).

\section{Paisagem conceitual: uma metáfora para o conceito de conceito}

Muitos estudos abordam a relação constitutiva entre metáfora e conceito (LAKOFF e JOHNSON, 2002; FELTES et al. 2014) e, portanto, nos servirmos de uma metáfora - paisagem conceitual - para pensar e construir o conceito de conceito (KEIL; 


\section{RevistAleph}

WILSON, 2000). Tomamos isto como um problema importante por considerar que o conceito de conceito é abstrato e de difícil compreensão e, no que tange ao nosso interesse como educador, acreditamos que a sua compreensão possa facilitar o processo ensino aprendizagem em diferentes áreas do conhecimento, especialmente nas ciências.

Ainda que a expressão "paisagem conceitual" tenha sido utilizada na língua inglesa (conceptual landscape) no domínio das artes (pintura e fotografia) e em estudos de pesquisa documental e sistematização de documentos (MICHEL al. 2008; POOLE, 2016), não encontramos o seu uso em nenhuma abordagem epistemológica e, portanto, a nossa construção teórica tem um grau de originalidade.

A partir da Teoria das Metáforas Conceituais (TMC), proposta originalmente por Lakoff e Johnson, em 2002, e das contribuições de outros autores para esta Teoria (ORTONI, 1993; FELTES et al. 2014), podemos inferir que a partir do domínio fonte "Compreender é Ver" derivam metáforas secundárias e enunciados metafóricos do domínio alvo que fazem alusão tanto ao aprimoramento do ver - "os conceitos são lentes cognitivas que nos auxiliam a enxergar o mundo" -, quanto à delimitação do que é visto, ou construído pelo pensamento: "os conceitos são construções do espírito"; "os conceitos são unidades de comunicação e/ou de conhecimento"; "os conceitos são tijolos elementares do universo intelectual do ser humano". Ainda que os enunciados metafóricos anteriormente citados nos auxiliem na compreensão da abstração que, normalmente, denominamos de conceito, decidimos ampliar esta compressão com a construção de uma outra metáfora secundária em alusão ao que é visto - conceito é paisagem - e da expressão metafórica derivada - paisagem conceitual - para aprofundar nossa discussão sobre os conceitos e, quiçá, chegar a uma compreensão ainda mais apurada deste termo.

A ideia de paisagem, como metáfora para a compreensão de conceitos abstratos na área científica, foi utilizada inicialmente por Sauer (1925) no clássico “A Morfologia da Paisagem", ao argumentar que a paisagem geográfica é formada pelo conjunto de formas naturais e culturais associadas a uma determinada área geográfica. Tim Ingold (1993), também adotou o temo paisagem cultural para criticar a oposição entre natureza e cultura e Waddington (1959), trabalhou a ideia de paisagem epigenética para explicar a epigênese e os caminhos epigenéticos possíveis que um organismo pode trilhar durante o seu desenvolvimento ontogenético. Mais recentemente, Cosgrove (1989) ressalta a 


\section{RevistAleph}

semiótica da paisagem para expressar uma leitura e interpretação desta como texto e/ou documento social.

Em "Temporalidade da Paisagem" (1993), Tim Ingold se refere às paisagens como um ato de memória, relacionado ao engajamento e ao agenciamento do observador no território, "em um ambiente impregnado de passado". Assim, a paisagem, enquanto conceito amplo, não indica um mundo externo e acabado, independente dos seres que o habitam, tampouco imagens ou ideias estáticas sobre ele. Elas são construções mentais e culturais derivadas da práxis do viver no mundo. Neste sentido de engajamento e agenciamento do observador, a paisagem deixa de ser uma unidade de observação passiva para incorporar e encarnar, na razão corpórea, os ciclos, os movimentos naturais, assim como as percepções derivadas da práxis do viver humano em uma determinada cultura (VARELA et al. 2003). É com esta perspectiva e entendimento que construímos o enredo metafórico "paisagem conceitual" para pensar o conceito de conceito.

Com relação à gênese dos conceitos, ela é complexa e perpassa várias fases e estádios de desenvolvimento, desde à criança ao adulto, com um amadurecimento quase completo na adolescência (VYGOTSKY, 1989). Sobre estas etapas e estádios, o referido autor faz distinções entre o pensamento por sincréticos, por complexos, por pseudoconceitos, por conceitos potenciais e por verdadeiros conceitos (VYGOTSKY, 1989). O referido autor nos ensina, ainda, que as formas primitivas de pensamento sincrético e por complexos vão diminuindo até a adolescência, ao mesmo tempo em que se estabelece o modo pelo qual o adolescente, e depois o adulto, fazem uso dos verdadeiros conceitos. No entanto, Vygotsky (1989) faz uma ressalva ao afirmar que estas etapas não seguem mecanicamente um fluxo linear, determinístico e determinado, em que cada fase começa quando termina a anterior. O processo é complexo e as várias formas podem mesmo coexistir na fase adulta.

Uma suposição comum, porém equivocada, é a crença de que os conceitos são livres criações simbólicas, independente da práxis do viver humano em um determinado contexto. Ao contrário, vários estudos mostram que estas criações estão, também, estruturadas em termos de padrões corporais, estados emocionais e contextos históricos (LAKOFF e JOHNSON, 2002; NIEDENTHAL, 2008; VYGOTSKY, 1989, ALVARENGA et al., 2014). 


\section{RevistAleph}

A paisagem conceitual se enquadra na reflexão epistemológica de Andrade (2018) quando o autor define o conhecimento como o:

produto do conhecer cultural humano, expresso através de enredos explicativos para enredos fenomênicos e de formulações conceituais, estando também incluso neste gênero de produto os objetos artísticos, mitológicos, religiosos, filosóficos, tecnológicos e científicos, abstratos ou concretos, criados ou recriados, aceitos e utilizados por uma determinada comunidade humana, mesmo que provisoriamente (p. 123).

E quando ele propõe um mecanismo gerativo para o fenômeno do conhecimento, qual seja:

um caminho processual humano, construtivo e criativo, mediado por passos e/ou sequências lógicas concatenadas de fazeres, dizeres e saberes, em resposta a uma demanda, pergunta, objetivo ou desejo, cujo produto explica, conceitua e/ou satisfaz o demandante e a comunidade que faz uso deste produto, mesmo que provisoriamente" (ANDRADE, 2018, p. 131).

Ao assumirmos a metáfora do caminho para pensar o mecanismo pelo qual o conhecimento é produzido, vislumbramos a ideia, também metafórica, de que o caminho pode se abrir, de vez em quando, em paisagens que ampliam o olhar epistemológico, ou seja, um "lugar de parada, de síntese provisória, inacabada e em vias de recomeçar" (SANCOVSCHI e KASTRUP, 2008). Este foi o "insight" para concebermos o conceito de conceito como paisagem conceitual.

Há de se fazer um alerta para afirmar que esta paisagem metafórica não deve ser tomada como uma imagem espontânea, capturada e fotografada por todo aquele ou aquela que cruza um determinado caminho do conhecimento. Como nos ensina Vygotsky (1989), o conceito aparece como resultado de um esforço mental e não como uma imagem gratuita, capturada como uma fotografia da realidade. $O$ cérebro não age como máquina fotográfica de captação e revelação de fotografias e o pensamento, enquanto processo e fenômeno emergente, não opera através da combinação simples e mecânica de folhear fotografias já captadas e armazenadas como se fosse um álbum. Pelo contrário, os processos do pensamento surgem com a linguagem e os conceitos são produtos deste processo que constitui o próprio pensamento. Este círculo virtuoso, proposto por Vygotsky (1989), se assemelha à recursividade das "coordenações de coordenações 


\section{RevistAleph}

condutuais consensuais" proposta por Maturana e Varela (1995), ao definir a linguagem. O traço comum entre os dois processos é a utilização funcional da palavra como meio de orientação voluntária da atenção - como meio de abstrair, isolar, sintetizar e simbolizar esses traços como símbolos. É importante ressaltar que os símbolos, para estes autores, emergem de um processo histórico e, assim, não são concebidos a priori. O conceito, da mesma forma, não surge como uma simples associação da palavra com os objetos da realidade, ele deve ser, necessariamente, construído. A semelhança entre o construtivismo histórico-cultural de Vygotsky (2007) e o autopoiético de Maturana e Varela (1995), especialmente na abordagem enativa (atuacionista) do segundo (VARELA et al. 2003), já foi apontado anteriormente por Sancovschi e Kastrup (2008). As referidas autoras mostram que tanto Vygotsky quanto Maturana e Varela, mesmo separados geográfica e historicamente, compreenderam que a cognição, a aprendizagem e a formação de conceitos são processos, são caminhos tortuosos, cheios de idas e vindas, com atalhos e um emaranhado de voltas que se entrelaçam como um rizoma (DELEUZE e GUATARRI, 1995), uma rede (CAPRA, 2002; LEVI, 2006) ou uma árvore do conhecimento (MATURANA E VARELA, 1995).

Destarte, convidamos o leitor para seguir os nossos passos (pressupostos) para compreender melhor o que estamos denominando de "Paisagem Conceitual":

1. O conceito é um termo ou expressão linguística. Usamos expressão linguística para afirmar que a construção e a emergência do conceito ocorrem entre sujeitos na linguagem, no sentido lato do linguajar, ou seja, incluindo todas as linguagens escritas, orais e gestual-visuais, como no caso da Língua Brasileira de Sinais - LIBRAS;

2. A relação entre linguagem e conceito surge como uma coemergência cognitiva entre o sujeito e o objeto, entre o sujeito e o mundo, engendrando o que apontamos anteriormente como representações, criações, avaliações e classificações;

3. A gênese do conceito surge na práxis do viver humano na linguagem, explicando, assim, o surgimento de objetos de pensamento e formulações conceituais mais universais, ou mais restritivas, dependendo da teoria subjacente e de seu uso por uma determinada comunidade;

4. Enquanto símbolos linguísticos e operadores de enlaces cognitivos, os conceitos favorecem a comunicação entre sujeitos, criando redes de produção e socialização do conhecimento;

5. A utilização de metáforas, além de ser muito comum em todas as línguas, auxilia a compreensão de conceitos abstratos como o próprio conceito de conceito, denominado aqui de paisagem conceitual; 


\section{RevistAleph}

6. Paisagens conceituais são paradas reflexivas e sínteses, com direito à saltos e atalhos, no caminho do conhecimento.

Se os pressupostos parciais explicitados acima foram seguidos e aceitos pelo leitor, o conceito de conceito, denominado aqui de Paisagem Conceitual, se enuncia como: Termo, ou expressão linguística, capaz de nomear, representar, criar, apreciar e comunicar um objeto de pensamento para o próprio sujeito que o expressa, ou para um interlocutor, significando para ambos o próprio objeto em questão, ou o processo pelo qual este objeto foi criado, identificado, descrito, nomeado, classificado e apreciado, como uma síntese, no caminho construtivo do conhecimento.

\section{Paisagem conceitual e o seu uso na educação}

Em nossa construção teórica, a paisagem conceitual surge como uma "parada reflexiva" no caminho construtivo do conhecimento. Quando surge, como produto da experiência e de uma intensa reflexão, ela possibilita um olhar atento, analítico e ampliado, tanto do passado, ao revelar o caminho trilhado para se chegar àquela posição epistemológica onde o autor se encontra, quanto do futuro, ao descortinar inúmeras possibilidades, perguntas e novos caminhos de abordagem, em passos subsequentes - sua heurística.

Para explicar melhor esta dupla mirada (passado e futuro), a partir das paisagens conceituais, daremos alguns exemplos retirados das obras de três autores que muito contribuíram para o campo da educação, quais sejam: o americano Jonhn Dewey (1859 1952), o brasileiro Paulo Freire (1921 - 1997) e o chileno Humberto Maturana. Embora tenham diferentes formações acadêmicas, eles se destacaram como educadores em diferentes contextos sociais, compartilham: uma epistemologia que valoriza o pensar reflexivo e o atuar do aprendiz, no mundo; uma concepção ética de respeito ao ser do aprendiz; e um posicionamento político de elogio à democracia e à prática da liberdade.

Para Dewey (1959), a educação é "uma reconstrução ou reorganização da experiência, que esclarece e aumenta o sentido desta e também a nossa aptidão para dirigirmos o curso das experiências subsequentes" (p.83).

Para Freire (2002), em sua oralidade dialética, educar 


\section{RevistAleph}

é tarefa daqueles que sabem que pouco sabem - por isto sabem que sabem algo e podem assim chegar a saber mais - em diálogo com aqueles que, quase sempre, pensam que nada sabem, para que estes, transformando seu pensar que nada sabem em saber que pouco sabem, possam igualmente saber mais (p. 25).

Para Maturana (1997), o educar

se constitui no processo em que a criança ou o adulto convive com o outro e, ao conviver com o outro, se transforma espontaneamente, de maneira que seu modo de viver se faz progressivamente mais congruente com o do outro no espaço de convivência. $O$ educar ocorre, portanto, todo o tempo e de maneira recíproca (p. 29).

Há de se ressaltar que não é nossa intenção fazer um resumo das obras destes três pensadores, o que nos propomos a fazer, mantendo a coerência deste ensaio, é apontar e comentar, dentre as várias paisagens conceituais identificadas nas suas respectivas obras, algumas poucas para expandir e, assim, oferecê-las como exemplos aos nossos leitores.

Assim, em Dewey, podemos destacar como paisagens conceituais: "experiência", "problematização", "princípio da continuidade", "liberdade intelectual", "educação progressiva", "hábito", entre outras (DEWEY, 1953, 1958 1959a, b, 1979a, b, 1980). Destacamos a "experiência" e, como consequência lógica conectada pelo próprio autor no enunciado de sua concepção de educação, a "reconstrução da experiência".

Em Freire, podemos destacar: "problematização", "palavra geradora", "educação bancária", "educação como prática da liberdade", "conscientização", "dialética", "autonomia", entre outras (FREIRE, 1969, 1970, 1992, 1998). Para o nosso interesse aqui, escolhemos a "conscientização".

Em Maturana, destacam-se: "autopoiesis", "fechamento operacional", "acoplamento estrutural", "deriva natural”, "objetividade entre parênteses", entre outras (MATURANA, 1997, 2000, 2001, 2002). Focamos os sentidos na autopoiesis, pois foi a partir da construção desta paisagem conceitual que o autor vislumbrou e percorreu outros caminhos no âmbito da biologia e fora dela. 


\section{RevistAleph}

Escolhidas as três paisagens conceituais nas obras dos educadores, o nosso desafio intelectual será o de mostrar como cada um chegou a cada uma delas e o que foi descortinado a partir de então.

\section{Experiência, como paisagem conceitual, em Dewey}

Nascido em 1859, John Dewey foi educado em um contexto que valorizava a prática religiosa e o fazer prático. Iniciou sua formação acadêmica na Universidade de Vermont, tendo despertado para a filosofia a partir da leitura de textos sobre o darwinismo (Teoria Evolutiva) e psicologia biológica (Teoria Pragmática do Conhecimento) que lhe mostraram uma concepção relativamente nova de "vida em ação". Seguindo a carreira acadêmica, doutorou-se pela Universidade Jonhs Hopkins, em 1884, defendendo uma tese sobre o filósofo alemão Immanuel Kant. A partir de sua crítica aos pressupostos da lógica pura, que valorizavam o pensamento em si, como se este fosse derivado de uma estrutura inerente ao sujeito, e não do resultado de situações de conflitos intermitentes advindos do acoplamento de ciclos fisiológicos e socioambientais, ele acabou por aderir ao pragmatismo (MURARO, 2008). Este termo, pragmatismo, de origem etimológica grega - pragmata, significando ação, de onde deriva a palavra prática, foi introduzido na literatura por Peirce, em 1878, para afirmar a relação entre conhecimento e conduta humana (JAMES, 1879). No âmbito desta corrente filosófica, Dewey vai afirmar que o lógico é expressão orgânica e inerente do prático e a mente não é estática e nem tampouco uma substância que, de algum modo, se distingue do corpo, em seu devir na cultura e na história (MURARO, 2008). Com este arcabouço teórico, ele afirmou também a sua emancipação do idealismo e das demais correntes dualistas que, especialmente em Descartes, separavam a mente do corpo (res cogitans e res extensa). Para Dewey, o conhecimento é produto do fazer humano e não de um estado transcendental. Para ele, o conhecimento é produzido a partir de respostas naturais do organismo, em situações de dúvidas e desafios, para as quais o organismo responde com investigação e ação (conduta), na experiência e na reconstrução da experiência (DEWEY, 1953 e 1958).

O pragmatismo deweyano concebe o homem como um ser de vontade e autônomo mas, essencialmente, social e, portanto, que atua sobre o mundo por meio de experiências individuais e compartilhadas, daí a importância que a paisagem conceitual 


\section{RevistAleph}

"experiência" adquire em sua filosofia, marcada pela supressão de todos os dualismos encontrados na filosofia tradicional: espírito / corpo; inteligência / ação; teoria / prática; saber / fazer (DEWEY, 1958).

Para se compreender a experiência em Dewey, é necessário compreender o que o autor nos ensina e alerta quando afirma que nem todo arco ação-reação-ação do sujeito produz aprendizado significativo. Para que isto ocorra, é necessário um esforço intelectual (reflexão) para descobrir as relações inerentes ao processo, como um todo, ou às associações particulares inferidas sobre o mesmo, o que caracterizaria a experiência reflexiva. Nesta mesma linha de pensamento, Dewey nos fornece também o que, na sua experiência como educador, se torna impedimentos para as experiências reflexivas: rotina mecânica e procedimentos coercitivos sobre o aprendiz posto que, em ambos, há uma recusa, por parte do aprendiz, em reconhecer a sua responsabilidade sobre as consequências oriundas das ações que se estabelecem na própria experiência (DEWEY, 1979b). Esta responsabilidade só é assumida pelo aprendiz quando o esforço da reflexão busca um significado na sua própria experiência. Assim, "a experiência é o resultado, o sinal e a recompensa desta interação do organismo e o ambiente que, quando se realiza plenamente, é uma transformação da interação, em participação e comunicação" (DEWEY, 1953, p.22).

Se o registro simbólico da experiência permite que ela possa ser comunicada por meio da linguagem (meta educacional), e também reconstruída pelo próprio sujeito, como uma experiência da experiência, surge-se assim a definição de Dewey para a educação, anteriormente enunciada, e a sua principal consequência para o aprendiz: “identificação simpática com o seu próprio destino" (DEWEY, 1979b, p. 161).

\section{Conscientização, como paisagem conceitual, em Freire}

Paulo Reglus Neves Freire (1921-1997) nasceu de uma família de classe média, na cidade de Recife (Pernambuco). Ele afirma que seus pais the deram um belo testemunho de respeito e querer-bem que o marcou para sempre. Ainda que tenha sofrido algumas dificuldades iniciais para estudar, formou-se em Direito, mas optou por não exercer essa profissão. Envolto em outra paixão - a educação - dedicou-se primeiramente aos problemas de gramática e linguagem, tornando-se professor de língua portuguesa aos 19 


\section{RevistAleph}

anos. Mais tarde, já trabalhando no Serviço Social da Indústria (SESI), sentiu-se desafiado por várias questões político-educacionais, especialmente 0 analfabetismo. Da preocupação à ação, Paulo Freire envolveu-se inteiramente com a alfabetização de adultos. A partir de suas experiências no campo educacional, produziu um caminho pedagógico no qual o alfabetizando fosse capaz de apropriar-se criticamente do próprio processo de alfabetização, como um ato de sua criação (GADOTTI, 1996; FREIRE, 2002; BLOIS, 2005).

Mais tarde, início da década de 60, já tendo desenvolvido uma concepção e uma prática educativa emancipadora, que o tornaria internacionalmente conhecido, e estando engajado em ações educativas que demonstravam que a leitura da palavra não poderia estar desvinculada da leitura do mundo, foi considerado como subversivo pelo regime militar, iniciado com o golpe de 64. Foi preso e, mais tarde, obrigado a exilar-se. Depois, já na condição de exilado, Freire nunca perdeu seu compromisso com os excluídos, estando eles na Bolívia, Chile, México, São Tomé e Príncipe, Moçambique, etc. Por suas andanças e práxis libertária transformou-se em um andarilho da esperança (GADOTTI, 1996; BLOIS, 2005).

Depois do seu retorno ao Brasil, após 16 anos de exílio, manteve a coerência política e seu grande compromisso com a causa da educação. Atuou de forma intensa em vários lugares e de muitas formas: militante, professor, administrador e escritor. Pouco antes de sua morte, em dia 2 de maio de 1997, Paulo Freire teria dito: "Eu nunca poderia imaginar a educação sem amor. Sou um educador, acima de tudo, porque amo" (MAYO, 2004).

Para se compreender a conscientização como paisagem conceitual em Freire torna-se necessário, primeiramente, apontar a grande influência das dialéticas de Hegel e de Marx no pensamento e na práxis educativa do autor (ANDRADE, 2005). Assim, para Freire, a educação é entendida como um processo que deve, necessariamente, levar o indivíduo a reconhecer não só a sua condição de indivíduo no mundo, mas, também, a sua condição de agente que cria o mundo. Chega-se a esse duplo reconhecimento através do movimento dialético das contradições internas entre a razão e o mundo material e das condições materiais do mundo, em que a razão existe. Assim, segundo a concepção freireana, o ato de leitura não pode estar dissociado da leitura do mundo e não se trata apenas de ler e conhecer as coisas do mundo mas, efetivamente, o de transformá-lo - o 


\section{RevistAleph}

que inscreve a educação como prática da liberdade. Freire compreendeu, no entanto, os limites da educação para operar o processo de mudança em condições objetivas desfavoráveis, razão pela qual direcionou sua atenção para o que ele a conscientização (FREIRE, 1969, 1970, 1992). Ainda que o termo conscientização, entendido como um processo pedagógico que desafia o aprendiz para que este se descubra enquanto corpo consciente de si mesmo e agente transformação do mundo, não tenha sido inventado por Paulo Freire (GADOTTI, 2001), o referido autor ressignificou, expandiu e o utilizou com tanta frequência para exprimir suas posições político-pedagógica que nós julgamos, a partir dos critérios explicitados neste ensaio, considerá-lo como uma paisagem conceitual na obra do autor. Para Freire, "não é possível compreender a vida social fora da existência dos antagonismos, fora da existência dos conflitos" (BLOIS, 2005, p. 44). É possível assumir um sentido amplo para o termo conflito e incorporar a ele a noção de problema, de situação problemática ou desafiadora. Na verdade, diz Freire, "o conflito parteja, é a parteira mesmo da consciência" (BLOIS, 2005, pg. 43). Dito isto, pode-se afirmar que, para Paulo Freire, "não há vida sem conflitos" e, no âmbito humano, são os conflitos e os problemas que, ao desafiarem o homem em sua relação com o mundo, facilitam o desencadeamento de um processo que alcança um certo patamar ou estado de consciência. A este processo, que pode ser variado, dependendo dos indivíduos em ação e das circunstâncias, denomina-se conscientização. É importante ressaltar que a conscientização não ocorre de forma automática, sempre que o indivíduo estiver diante de um conflito nem é, muito menos transferida. No entanto, pode-se facilitar o desencadeamento do processo de conscientização através da problematização. Isso explicaria a insistência de Freire para a importância dos educadores-educandos se predisporem, junto aos seus educandos-educadores, a uma problematização sistemática e permanente, pois, como dizia ele: "a problematização é a tal ponto dialética que seria impossível alguém estabelecê-la sem comprometer-se com o seu processo" (FREIRE, 2002, p. 82).

No entanto, ele nos fez um alerta, qual seja,

a conscientização não pode parar na etapa do desvelamento da realidade. A sua autenticidade se dá quando a prática do desvelamento da realidade constitui uma unidade dinâmica e dialética com a prática da transformação da realidade (FREIRE, 1992, p.103). 


\section{RevistAleph}

Destarte, se a palavra conscientização, em sua acepção original, fazia referência a uma tomada de consciência - uma apreensão crítica da realidade - em Paulo Freire, ela se converte, também, em uma prática de liberdade.

\section{Autopoiesis, como paisagem conceitual, em Maturana}

Humberto Maturana Romecín nasceu em Santiago do Chile, em 1928, de uma família de classe média. Tendo em vista a separação de seus pais, ainda na infância, foi criado quase que exclusivamente por sua mãe, de quem guarda lembranças de uma relação amorosa e de grande respeito para com a autonomia dos filhos, o que o marcou, profundamente, por toda vida.

Estudou medicina, no Chile, até o $4^{\circ}$ ano e graduou-se em biologia, na Inglaterra. Doutorou-se na Universidade de Harvard e participou de um dos mais famosos grupos de neurobiologia da década de 1950. Sua curiosidade científica foi despertada, desde muito cedo, para duas questões fundamentais: a percepção e as relações constitutivas dos seres vivos. A partir das reflexões suscitadas por estas duas questões, elaborou todo um arcabouço teórico denominado Biologia da Cognição (MATURANA, 2001; MATURANA e VARELA, 1980).

Para se compreender o paradigma da Biologia da Cognição, incluindo o seu uso e aplicação em outras áreas do conhecimento, torna-se necessário aprender um conceito fundamental, qual seja, autopoiesis. Assumindo que aprender não é memorizar enunciados nem definições, reconstruímos o caminho pelo qual Humberto Maturana construiu o referido conceito, em parceria com Francisco Varela, no Chile. Visto que este caminho de construção é muito longo para descrever neste ensaio, vamos resumir a história em algumas poucas etapas que consideramos importantes, chamando atenção para o caminho processual de construção do conceito e, como estamos propondo aqui, ressaltando o seu valor heurístico como paisagem conceitual. 


\section{RevistAleph}

\section{Pergunta}

Nos idos da década de 1960, quando Maturana já havia retornado ao Chile depois de um longo período de formação na Inglaterra, consta que, quando o professor foi perguntado por um jovem estudante chileno sobre "o que é um ser vivo?, ele respondeu a pergunta com honestidade intelectual afirmando que não sabia responder, que ao seu ver a Biologia não tinha uma resposta e que, portanto, tratava-se de uma pergunta muito importante. Na sequência ele solicitou ao estudante que lhe desse um ano para pensar sobre o assunto e que o mesmo se matriculasse na disciplina no ano seguinte, quando esperava ter uma resposta satisfatória. Há de se ressaltar que, na década de 60, e diríamos que até hoje, a resposta clássica da Biologia para a pergunta se resume a uma lista de predicados sobre o vivo, tais como: nascer, crescer, reproduzir e morrer. Esta resposta clássica não satisfazia Maturana, pois o mesmo considerava que a pergunta solicitava uma explicação e não uma lista de características do vivo.

\section{Organização}

Durante o ano reflexivo, Maturana buscou investigar a questão de várias maneiras. Se uma lista de predicados não era a resposta, o que ele deveria procurar, ou elaborar, para responder à pergunta formulada pelo estudante? Um grande avanço foi dado quando, partindo da premissa que uma só palavra - vida - é usada para denotar todas as espécies que compõem a biodiversidade do planeta, ele formulou a hipótese de que todos os seres vivos compartilham uma mesma organização e passou, então, a se perguntar que organização seria essa.

Em conversa com um amigo microbiologista - Antônio Contreras - Maturana aprendeu sobre o dogma que imperava na biologia naquele momento, qual seja, a sequência linear do DNA codificando PROTEÍNAS. Antônio Contreras lhe mostrava como o DNA era transcrito em RNA e este traduzido em PROTEÍNAS. Na conversa, Maturana lhe fez uma pergunta lógica mas, de alguma forma, perturbadora: “Antônio, quem produz o DNA?". “Ora”, respondeu Antônio, "as enzimas". "E o que são as enzimas?”, perguntou Maturana. "Proteínas", respondeu Antônio. Maturana, então, pensou um pouco e já como um primeiro "insight" do que ele buscava - uma organização comum a todos os seres 


\section{RevistAleph}

vivos - afirmou: "a sequência linear e hierárquica entre estas biomoléculas não condiz com a dinâmica molecular interna à célula pois, a rigor, esta dinâmica é circular, ou seja, o DNA influencia na produção das PROTEÍNAS e estas na produção do DNA". A ideia de uma circularidade para a organização que ele buscava compreender estava, assim, concebida. Ainda que a conversa sobre a codificação das proteínas pelo DNA tenha sido muito proveitosa, foi a circularidade do sistema que despertou a atenção e a reflexão de Maturana para a organização que ele buscava.

Neste caminho reflexivo, ele fez uma distinção entre organização e estrutura, sendo a primeira (organização), pensada como as relações entre os componentes, ou as partes, de um determinado sistema, que permanecem invariantes no tempo (uma abstração). A segunda (estrutura), foi concebida como uma realização, uma efetivação concreta da primeira (organização). Assim, no caso do vivo, a estrutura é molecular. Neste caso, enquanto materialidade, a estrutura pode variar em seus constituintes desde que não comprometa a organização invariante que define o sistema vivo, enquanto uma unidade autônoma. Na continuidade de sua reflexão sobre a circularidade do sistema, ele avançou para a ideia de recursividade e, como uma marca distintiva do paradigma nascente - Biologia da Cognição - concebeu o fechamento operacional do sistema, denominado por ele de "clausura operacional", rompendo com a ideia de instrução, de transferência, de input e output de informação (Maturana, 1997, 2001).

\section{Explicação}

Partindo da premissa básica que a pergunta do estudante solicitava uma explicação, ou seja, um mecanismo gerativo que, posto a operar, gerasse o fenômeno a explicar, qual seja, o vivo, Maturana levou alguns meses para formular e nos oferecer a seguinte proposição explicativa para a fenomenologia do vivo e, por extensão, para o que ele denominou de organização do ser vivo: uma rede concatenada da produção de moléculas constitutivas, da produção de moléculas constitutivas, que regenera, continuamente, a rede molecular que as produz e, ao mesmo tempo, especifica o domínio, através de uma fronteira física, no qual esta mesma rede se realiza, determinando, assim, sua topologia no espaço físico (MATURANA e VARELA, 1980). 


\section{RevistAleph}

É importante notar que o mecanismo gerativo proposto acima enfatiza uma dinâmica molecular, recursiva, operacionalmente fechada, mas não especifica ou enfatiza nenhuma biomolécula. Para Maturana e Varela (1995), em qualquer lugar do universo onde ocorrer uma dinâmica molecular, tal qual esta que foi enunciada para definir a organização do ser vivo, poderá ser chamada de vida, independente do tipo de moléculas utilizadas em sua estrutura. Há de se ressaltar que, para Maturana, os seres vivos têm uma organização fechada, ou seja, não podem ser especificados de fora para dentro, mas são termodinamicamente abertos, ou seja, incorporam, processam e captam energia de outras biomoléculas que se entrecruzam com o sistema, sem modificar sua organização invariante (MATURANA, 1997; MATURANA e VARELA, 1995).

\section{Nomeação}

Como nenhum autor havia formulado tal dinâmica e tal enunciado anteriormente, Maturana sentiu a necessidade de nomear o conceito recém construído. 0 nome surgiu durante uma conversa de Maturana com um casal de amigos. A mulher comentava que ela estava fazendo uma tese sobre D. Quixote e que o dilema do protagonista era o de estar sempre entre a luta e a poesia, entre a práxis e a poiesis. Eureca! Poiesis, do grego, criação. Faltava somente adicionar o sufixo auto, de próprio, para criar a palavra que ele buscava para nomear o conceito recém criado: autopoiesis. Este significa autocriação, autoprodução. Tal trabalho teórico o tornou internacionalmente conhecido.

O conceito de autopoiesis, aparentemente simples e ingênuo, criou e impulsionou todo um arcabouço teórico denominado de Biologia da Cognição, ganhou o mundo e vem influenciando diversas áreas do conhecimento, tais como: administração (BASTIAS, 2000); direito (LUHMANN, 1983; NEVES, 2003); educação (ANDRADE, 2005); epistemologia (MOREIRA, 2004); imunologia (VAZ; ANDRADE, 2017); inteligência artificial (DUPUY, 1996); linguística (EICHEVERRIA, 1994); neurobiologia (LETELIER et al. 2003); psicologia (SANCOVSHI e KASTRUP, 2008); sociologia (FREITAG, 1974), terapia de família (DELL, 1986), entre outros. É a partir desta constatação que dizemos que alguns conceitos se alargam por sua heurística e, portanto, podem ser entendidos como paisagens conceituais. 


\section{RevistAleph}

A partir da autopoiesis, Maturana rompeu radicalmente com o sentido habitual da noção de cognição - entendida como captação e processamento de informações do mundo exterior pelo organismo - e, no bojo desta ruptura, nos ofereceu um novo paradigma para compreensão deste fenômeno. Para este novo paradigma, a cognição é a ocorrência de um duplo ato de criação (poiesis) que configura tanto o vivo, quanto o mundo. Se o mundo no qual vivemos é criado com o nosso próprio viver, surge a indissociabilidade entre viver, fazer e conhecer. Neste sentido, não se pode mais evitar a analogia do fenômeno do conhecer com o trabalho do artista, pois só se conhece assim: em ato de criação - ato radical, porque nada preexiste a ele - nem o vivo, nem o mundo.

A aceitação do modelo explicativo traz enormes consequências para o nosso ser e para o nosso fazer cotidiano. Assim, no campo educacional, rompe-se com a ideia de instrução e/ou de transferência de informações de um emissor (professor) para um receptor (aluno), radicalizando o que se entende por construtivismo. Enquanto uma reflexão sobre o conhecer, surge uma epistemologia que leva em conta a biologia do observador. Enquanto uma reflexão sobre as relações humanas, surge uma explicação original para o fenômeno da linguagem.

Como a linguagem só pode surgir com a aceitação da legitimidade do outro, fundado na relação, ressalta-se a essencialidade do amor e da ética para o surgimento do fenômeno social. Para além destas temáticas, o novo instrumental teórico tem permitido o estudo de outras questões até então pouco abordadas como, por exemplo, a consciência (MATURANA, 2001; MATURANA; POERKSEN, 2004).

\section{Considerações finais}

A construção da paisagem conceitual foi iniciada a partir de uma reflexão sobre o conhecimento, expressa com a metáfora: conhecimento é caminho. No âmbito desta reflexão, postulamos que as paisagens conceituais permitem ao caminhante uma dupla mirada, para o passado e para o futuro, e se torna, assim, um bom guia cartográfico para deslocamentos teóricos e planos de ação futuros. Quando se mira para o passado, é possível distinguir o caminho trilhado, os caminhos errantes, os obstáculos vencidos, as bifurcações e os atalhos. Quando se mira para o futuro, é possível formular novas perguntas, vislumbrar novos caminhos a serem trilhados e novas áreas a serem 


\section{RevistAleph}

exploradas. A ação pedagógica pode tirar proveito deste duplo movimento da atenção e do olhar, seja para servir de guia de construção / reconstrução do caminho pelo educando, seja para problematizar e orientar a abertura de novos caminhos a serem investigados e, quiçá, percorridos.

Ainda que as paisagens conceituais sejam conceitos, nem todos os conceitos se efetivam como paisagens conceituais. As paisagens conceituais se superpõem aos conceitos semânticos, exclusivos, hipotéticos, operacionais e heurísticos. Embora as paisagens conceituais possam revelar novos caminhos possíveis e configurar novos conceitos e até novas realidades, elas não se confundem e nem se apresentam com o mesmo status das rupturas paradigmáticas kuhnianas. Elas não se confundem, tampouco, com os mapas conceituais, ainda que possam ser utilizadas nos mesmos. Advogamos que a sua especificidade e funcionalidade possa contribuir para a educação, seja como formulação para o conceito de conceito, seja como instrumento de análise ou plano de ação docente na produção e socialização do conhecimento.

Na nossa experiência acadêmica, observamos que são poucos os autores que chegam a produzir paisagens conceituais em seus respectivos domínios de atuação, no entanto, quando estas paisagens conceituais são formuladas, elas se tornam mirantes de visitação de inúmeros aprendizes e mesmo de investigadores experientes naquela área do conhecimento. Exemplificamos esta utilização das paisagens conceituais, de forma breve, para ressaltar as contribuições de três expoentes - Dewey, Freire e Maturana, para a área da Educação. Estas paisagens conceituais servem como mirantes importantes para apreciar campos temáticos interdisciplinares, analisar criticamente as obras dos diferentes autores e, também, como instrumentos para elaboração de planos de aula, planejamento de disciplinas e projetos de investigação.

Não nos passa desapercebido a possibilidade do docente e/ou discente, ao percorrer estes caminhos e alcançar estas paisagens conceituais, construir relações entre as mesmas e, de forma ampla, criar paisagens ainda maiores, que vão para além dos conceitos de conceitos - as paisagens epistemológicas.

\section{REFERÊNCIAS}

ABBAGNAMO, N. Dicionário de filosofia. 5a ed. São Paulo: Martins Fontes, 2007. 


\section{RevistAleph}

ANDRADE, L. A. B. Conhecimento é caminho: da metáfora ao mecanismo gerativo. Ciências \& Cognição, Vol. 23(1) 117-137, ISSN 1806-5821, 2018, Disponível em:

http://www.cienciasecognicao.org/revista/index.php/cec/article/view/1462/pdf_107, acessado em 7/5/2019.

ANDRADE, L.A.B. \& SILVA, E.P. O conhecer e o conhecimento: comentários sobre o viver e o tempo. Ciências \& Cognição Vol. 4: 35-41, 2005a. Disponível em:

http://www.cienciasecognicao.org/revista/index.php/cec/article/view/508/279, acessado em 13/4/2019.

ANDRADE, L.A.B. \& SILVA, E. P. Dialética, diálogo e conversa: consonâncias e dissonâncias epistemológicas entre Freire e Maturana. Revista Educação Brasileira, 55, V.27, p.51-77, 2005b.

BASTIAS, L.E. La autopoiesis en la organización: Fundamento teórico para la administración propuesto desde el paradigma sistemo-cibernetico. Anales del XVII Encuentro Nacional de Escuelas y Facultades de Administración y Economía, 2000.

BLOIS, M. M. Reencontros com Paulo Freire e seus amigos. Fundação Euclides da Cunha, Niterói, 2005.

BORGES, J. L. Fumes, o memorioso. In: Fiç̧ões. Editora Globo, São Paulo, 1997, Disponível em: http://www.cfh.ufsc.br/ wfil/funes.htm. Acessado em 30/5/2019.

CAPRA, F. As conexões ocultas. Ciência para uma vida sustentável. Trad. Marcelo Brandão Cipolla. Editora Cultrix. São Paulo, 2002.

COSGROVE, D. A geografia está em toda parte: cultura e simbolismo nas paisagens humanas, 1989, In: Paisagem, Tempo e Cultura. Correa, R. L.; Rosendahl, Z. (Orgs.) Rio de Janeiro: EDUERJ, 1998.

DELEUZE, G. e GUATARRI, F. O que é filosofia? Editora 34, Rio de Janeiro, 1992.

DELEUZE, G. e GUATARRI, F. Mil Platôs - capitalismo e esquizofrenia, vol. 1, Ed. 34, Rio de Janeiro, 1995.

DELL, P. Bateson e Maturana: verso um fondazione biológica delle scienze sociali. Terapia Familiare, 21:35-60, 1986.

DUPUY, J-P. Nas origens das ciências cognitivas. São Paulo: Unesp, 1996.

DEWEY, J. Experience and nature. New York: Dover Publications, Inc., 443p., 1958.

DEWEY, J. Essays in experimental logic. New York: Dover publications, 444p. 1953.

DEWEY, J. Reconstrução em filosofia. Tradução: Antônio Pinto de Carvalho. São Paulo: Nacional, 1959b.

DEWEY, J. Como pensamos e como se relaciona o pensamento reflexivo com o processo educativo: uma reexposição. Tradução: Haydée Camargo Campos. 4a ed. São Paulo: Nacional. Atualidades pedagógicas; vol. 2. 292p., 1979a.

DEWEY, J. Democracia e educação. Tradução: Godofredo Rangel e Anísio Teixeira. São Paulo: Nacional. Atualidades pedagógicas; vol. 21. 416p., $1979 \mathrm{~b}$.

DEWEY, J. Vida e educação. Tradução de Anísio Teixeira. In: Os Pensadores. São Paulo: Abril Cultural,. V. p.107 - 191, 1980.

EICHEVERRIA, R.. La ontologia del lenguage. Dólmen ediciones, Santiago, Chile. 1994.

FELTES, H. P. M.; PELOSI, A. C. \& LIMA, P. L. C. Cognição e Metáfora: a Teoria da Metáfora

Conceitual. p. 88 - 113. In: Cognição e Linguística: explorando territórios, mapeamentos e 


\section{RevistAleph}

percursos. Orgs: Pelosi, A. C.: Feltes, H. P. M \& Farias, M. P. E. 2. ed., rev. e atual. Educs, Caxias do Sul, RS, 2014.

FREIRE, P. Educação como prática da liberdade. Paz e Terra, Rio de Janeiro, 1969.

FREIRE, P. Pedagogia do Oprimido. Paz e Terra, Rio de Janeiro, 1970.

FREIRE, P. Pedagogia da Esperança: um reencontro com a Pedagogia do Oprimido. Paz e Terra, Rio de Janeiro, 1992.

FREIRE, P. Pedagogia da Autonomia: saberes necessários à prática educativa. Paz e Terra, Rio de Janeiro, 1998.

FREIRE, P. Extensão ou comunicação? 12ạ ed. Paz e Terra, Rio de Janeiro, 2002.

FREIRE, P. e HORTON, M. O caminho se faz caminhando: conversas sobre educação e mudança social. Editora Vozes, Petrópolis, 2003.

FREITAG, B. Habermas e a teoria do conhecimento como teoria social. Debate e crítica, Revista de Ciências Sociais. São Paulo: Hucitec, no 4: 61- 82, 1974.

GADOTTI, M. Paulo Freire: uma biobibliografia. Cortez, São Paulo. Instituto Paulo Freire, Brasília, DF. UNESCO, 1996.

INGOLD, T. The perception of the environment: essays on livelihood, dwelling and skill. London/ New York: Routledge, Taylor \& Francis e-Library, 2002.

JAMES, W. Pragmatism, Revue Philosophique, vol. VII (1879), traduzido por Mariconda, P. R. In: Os Pensadores, p.9 - 22, Abril Cultural, 1974.

KEIL, F. C. \& WILSON, R. A. The concept concept: the way ward path of cognitive science, p.1 - 11, Blackwell Publischers Ltd. USA. 2000.

KUHN, T. A estrutura das revoluções científicas. Tradução de Beatriz Viana Boeira e Nelson Boeira. São Paulo: Perspectiva, 1978.

LAKOFF, G. e JOHNSON. M. Metáforas da vida cotidiana, 360p., Mercado de Letras Edições, EDUC, Campinas, SP, 2002.

LETELIER, J. C,; MARAN, G. e MPODOZIS, J. Autopoietic and (MR) systems. Journal of Theoretical Biology. 222: 261-272, 2003.

LEVY, P. As tecnologias da inteligência: o futuro do pensamento na era da informática: Editora 34, Rio de Janeiro, 2006.

MAYO, P. Gramsci, Freire e a educação de adultos: Possibilidades para uma ação transformadora. Artmed, Porto Alegre, 2004.

MATURANA, H. A ontologia da realidade. Editora UFMG, Belo Horizonte, 1997.

MATURANA, H. O que se observa depende do observador. p.61 - 66. In: Gaia - Uma teoria do conhecimento. Editora Gaia, São Paulo, 2000.

MATURANA, H. Cognição, ciência e vida cotidiana. Editora UFMG, Belo Horizonte. 2001.

MATURANA, H. Emoções e linguagem na educação e na política. Editora UFMG, Belo Horizonte, 2002.

MATURANA, H. e POERKSEN, B. From Being to Doing: The origins of the Biology of Cognition. Carl-Auer system, Heidelberg, Germany, 2004.

MATURANA, H. e VARELA, F. Autopoiesis and cognition. The realization of the living. D. Reidel Publishing Co, Dordecht. Holland,1972/1980. 


\section{RevistAleph}

MATURANA, H. e VARELA, F. A árvore do conhecimento: as bases biológicas do entendimento humano. Psy II, Campinas,1995.

MICHEL, I, S ;VARGO, S. L. e LUSCH, R. F. Reconfiguration of the conceptual landscape: a tribute to the service logic of Richard Normann. J. of the Acad. Mark. Sci. 36:152-155, 2008.

MOREIRA, M. A. A epistemologia de Maturana. Ciência \& Educação, v. 10, n. 3, p. 597-606, 2004.

MURARO, D. A importância social do conceito na concepção de filosofia e educação de John

Dewey, Childhood \& Philosophy, Rio de Janeiro, v. 4, n. 8, 2008.

NEVES, M. Von der Autopoiesis zur Allopoiesis des Rechts. In: Rechtstheorie, Berlin, v. 34,n. 2, p. 245-268, 2003.

NIEDENTHAL, P. M. Emotion concepts. In: Handbook of Emotion, eds M. Lewis, J. M., 2008.

ORTONI, A. Methaphor, language, and thought In: Ortony, A (Org). Methaphor and thought.

Cambridge University Press, $2^{\text {a }}$ ed. Nova York, 1993.

POLLIO, H. R.; SMITH, M. K. \& POLLIO, M.R. Figurative language and cognitive psychology, In: Language and cognitive process, 5(2), 141 - 167, 1990.

POOLE, A. H. The Conceptual Landscape of Digital Curation. Journal of Documentation, 72, no. 5, 2016. disponível em:

https://www.researchgate.net/profile/Alex_Poole/publication/301200534_The_Conceptual_Land scape_of_Digital_Curation/links/59ed01bc4585151983ccd819/The-Conceptual-Landscape-ofDigital-Curation.pdf. Acessado 15/4/2019.

RUSSELL, B. Misticismo e Lógica, Trad. Olviva, A. \& Cerqueira, L. A. Zahar Editores, Rio de Janeiro, 1977.

SANCOVSHI, B. e KASTRUP, V. Algumas ressonâncias entre a abordagem enativa e a psicologia histórico-cultural. Fractal Revista de Psicologia, v. 20 - n. 1, p. 165-182, Jan./Jun. 2008.

SAUER, C.O. A morfologia da paisagem (1925). In: Paisagem, Tempo e Cultura. Correa, R.L.; Rosendahl, Z. (orgs.). Rio de Janeiro: EDUERJ, 1998.

ULPIANO, C. Acontecimento e campo de poder, acervo Claudio Ulpiano, 1989a, disponível em: https://acervoclaudioULPIANO.com/2016/11/15/aula-de-05041989-acontecimento-e-campo-dopoder/ . Acessado em 20/5/2019.

ULPIANO, C. Acontecimento e sentido, acervo Claudio Ulpiano (1989b), disponível em:

https://acervoclaudioULPIANO.com/2017/09/19/aula-de-12041989 acontecimento-e-sentido-2-

2/). Acessado em 20/5/2019.

VARELA, F. J.; THOMPSON, E. \& ROSCH, E. A mente incorporada: ciências cognitivas e experiência humana. Editora Artmed, Porto Alegre, 2003.

VYGOTSKY, L.S. Pensamento e linguagem. São Paulo: Martins Fontes, 1989.

VAZ, N. M. \& ANDRADE, L. A. B. The Epigenetic Immune Network. Constructivist Foundations.

v.13, p.141-159, 2017. Home page:

[http://www.univie.ac.at/constructivism/journal/articles/13/1/141.vaz.pdf].

VUILLEMIN, J. Conceito In: Enciclopédia Einaudi, vol. 37, Imprensa Nacional - Casa da MoedaLisboa, Portugal, 1997.

WADDINGTON, C. H. Canalization of development and genetic assimilation of acquired characters. Nature, 183: 1654-1655, 1959.

Data de envio: 04/04/2019

Data de aceite: 16/06/2019 